\title{
Do select macroeconomic factors drive momentum returns?
}

\author{
A. Balakrishnan ${ }^{1 *}$ and Nirakar Barik²
}

\begin{abstract}
In this paper, we examine the presence of short-term and long-term momentum returns in Indian stock market. The study also tries to shed light on the power of asset pricing models and select macroeconomic variables in explaining momentum returns. The results confirm the presence of short-term and long-term momentum returns in Indian stock market. It is also found that Carhart four-factor model's performance is relatively superior to other factor models such as one factor capital asset pricing model and Fama-French three-factor model in terms of capturing momentum returns. Finally, macroeconomic variables which are considered for analysis do not have any power to explain momentum returns.
\end{abstract}

Keywords: Momentum returns, Capital asset pricing model, Fama-French model, Macroeconomic variables JEL Classification: G12

\section{Introduction}

In financial research, it is an established fact that future stock returns can be predicted by stock price information. So that, investors can earn abnormal returns from stock market by using strategies based on prior returns. Globally, two prominent trading strategies based on stocks' past returns are used by large body of researchers, namely momentum and contrarian strategies. Contrarian strategy talks about price reversal which means past losers are future winners and past winners are future losers (see $[8,9])$. That means shorting the past winners and holding past losers generates abnormal returns for investors if they rank and form portfolios of stocks based on their long-term (3-5 years) past returns. On the other hand, momentum strategy is based on the hypothesis of price continuation which means past winners will remain future winners and past losers will continue to lose in future (see [17]. In the case of momentum strategy, investors need to sell past losers and buy past winners to earn

\footnotetext{
${ }^{*}$ Correspondence: abalki22@gmail.com

${ }^{1}$ Department of Banking Technology, School of Management,

Pondicherry University, Pondicherry 605014, India

Full list of author information is available at the end of the article
}

abnormal returns. This can be achieved by the investors if they form portfolios based on past returns of stocks over a shorter time period of 3-12 months.

Momentum behaves in a different manner compared to other asset pricing anomalies such as size, value, profitability, asset growth, and human capital in terms of earning returns. The returns from other anomalies fade away when the information related to it becomes public as investors try to maximize their profit by exploiting it. However, it is not same in the case of momentum as the sources of momentum are mysterious facts for the investors pursuing wealth enhancement. Thus, it has drawn significant attention of the researchers and practitioners as it is an economically viable trading strategy giving significant returns on stocks. Further, the strategy is being used by the investors almost in all the equity markets across the world. Jegadeesh and Titman [17] (hereafter JT-1993), De Bondt and Thaller [8, 9], Shen et al. [30], Schaller [25], Pirrong [22] document that both the strategies tend to earn abnormal returns in short-term and long-term time horizon.

Researchers are divided into two groups as to the debate on sources of momentum returns. One group attributes it to the rational sources and finds that 
underlying momentum returns can be explained by certain common risk factors, whereas others are of the view that irrational/behavioral sources such as investors underreaction (overreaction), and sentiments are the main sources of momentum returns.

Chen et al. [3] find that momentum returns are systematically priced by certain macroeconomic risk factors such as spread between long- and short-term interest rates, expected and unexpected inflation, industrial production, and spread between high- and low-grade bonds. Fama and French [10] reveal that firm characteristics which are otherwise known as anomalies/risk factors like size, $\mathrm{P} / \mathrm{E}$, cash flow/price, and book-to-market equity are the sources of momentum returns. Conrad and Kaul [5] and Berk et al. [2] also report that systematic risk factors are responsible for momentum returns. Further, they also find that cross-sectional variation in mean return plays an important role in explaining momentum returns in both shorter and longer time horizons. Moskowitz and Grinblatt [20] document a strong momentum effect in industry components of stock returns and confirm that these returns can be explained by momentum anomalies of individual stocks. Jhonson [18] is of the view that momentum returns can be captured by an enhanced model which includes standard asset pricing anomalies along with growth rate shocks as additional risk factor. Sadka [23] demonstrates that market should consider liquidity risk factor in addition to other systematic risk factors to get a better explanation about momentum returns. Sagi and Seasholes [24] find that three new systematic risk factors such as revenue, cost, and growth options that can drive momentum. Finally, they conclude that momentum strategies that consider firms with high revenue growth volatility, low costs, and valuable growth options outperform the traditional momentum strategies by five percent per year.

Contrary to above findings, some researchers contend that irrational sources such as investors' sentiment, overreaction, or underreaction are the main reasons of momentum returns. Barberies et al. [1] find that irrational sources tend to drive momentum returns. They also corroborate that underreaction or overreaction of the investors to good news or bad news about a specific firm such as earning announcement drives momentum returns. Daniel et al. [7] employ a model based on overreaction to private information and reveal that predictability of returns becomes stronger with greater information asymmetries. Supporting the above facts, Grinblatt and Maskowiz [14] suggest if investors consider additional factors such as seasonal effects and tax environment in their strategies, they can earn greater abnormal returns than others. In addition to the above findings, Chui [4] finds another irrational source of momentum, namely individualism, which is positively related to the momentum returns. Some authors attribute momentum returns to the "Disposition effect." Increase or decrease in stock prices due to investors' behavior of buying or selling stocks based on what others do is termed as disposition effect. A bunch of literature (see [11, 13, 15, 29] empirically examines and reports that disposition effect results in momentum returns in stock market.

The macroeconomic variables are known as the economic fundamentals of any country which have direct or indirect impact on the capital market. Evidences for the macroeconomic variables as sources of momentum returns are prevalent across the stock markets around the world. Again, there are differences in the opinion among researchers about this fact. While some of the researchers report macroeconomic variables have positive impact in explaining momentum returns, some find that they don't have any power to capture the momentum returns.

Griffin et al. [12] examine the power of macroeconomic risk in explaining the momentum returns. The sample includes the stocks of 39 countries across the globe. The study finds that neither an unconditional model of Chen et al. [3] nor a conditional model of lagged instruments provides any proof that macroeconomic risk variables can explain momentum returns. They also find a strong presence of momentum everywhere which is economically large and statistically reliable. Contrary to Griffin et al. [12], Sehgal and Jain [28] exhibit that the unexplained momentum returns in Indian stock market are explained by both rational and irrational sources. They also reveal that lagged macroeconomic variables have the power of explaining the underlying price momentum of Indian stocks.

Hutchinson and O'Brien [16] verify if there is any connection between time series momentum strategies and business cycle. The results show that linear macroeconomic factor model is unable to explain momentum returns. However, these macroeconomic variables become statistically significant once they are included in a model which allows the coefficients to change over the time. Cooper et al. [6] examine the power of global macroeconomic risk in explaining abnormal returns generated from portfolios. By considering different asset classes of different countries (USA, UK, Continental Europe, Japanese, country equity index futures, currencies, government bonds, and commodity futures) and forming a total of 48 portfolios, the study finds that global macroeconomic risk can explain the abnormal returns on various assets from different countries. Liu et al. [19] verify whether macroeconomic factors influence each firm differently by predicting the return from macroeconomic variables. They also examine the power of these variables in capturing momentum payoff. The study follows 
the CS (2002) methodology and finds that if the returns are predicted by using macroeconomic variables, the past winners produce higher expected returns and past losers generate lower expected returns. It also reports that discount rates of winner go downward, whereas discount rates of losers move upward.

A handful of works which have been carried out by researchers in Indian context to examine the effect of macroeconomic variables in explaining the momentum returns. However, some studies have tested other factors of asset pricing such as size, value, leverage, profitability, and human capital and found positive impact in Indian stock market. Sehgal and Balakrishnan [26] examine the availability of systematic return pattern in stock returns and find a reversal in long-term returns and continuation in short-term returns. The authors also find that contrarian strategies provide moderate positive returns, whereas the momentum investment strategies provide strong positive returns. Sehgal and Balakrishnan [27] test the power of prominent risk models to get an explanation about the momentum returns. Their results suggest that CAPM is unable to capture the momentum returns, whereas the FF-3 factor model gives partial explanation of the momentum returns. Sehgal and Jain [28] verify the presence of both short-term momentum and long-term contrarian pattern in Indian stock market. They observe a strong short-term momentum pattern which provides high returns in India. However, they also report a weak reversal pattern in the case of long-term momentum strategies after controlling the short-term momentum effect. Narayan et al. [21] try to find out sources of returns in Indian stock market. They suggest that returns disappear once they consider some risk factors along with a range of macroeconomic variables.

Despite plenty of debates about the sources of momentum returns, a conclusive result is yet to be arrived at about whether the systematic risk factors/rational sources or irrational sources are the drivers of momentum returns. Further, it is evident that the performance of Indian capital market has been consistently on the rise and resulting in deriving the investors' reaction/ sentiment. Hence there is a researchable question that whether the investors' sentiment triggers price fluctuations which may cause price momentum. So this study attempts to verify if short-term and long-term momentum returns continue to exist in Indian stock market. Next, we examine the power of prominent risk models in explain the momentum returns. Further, the study also examines whether select macroeconomic variables can be considered as driving forces of momentum returns.

\section{Data}

The study takes monthly adjusted closing share prices ${ }^{1}$ data of 482 companies for the period from July 2002 to November 2018. The companies that are taken for this study are part of Bombay Stock Exchange (BSE)-500, which is broad based market index in India which is one of the giants of Indian secondary equity markets covering majority of the trading activities. It also accounts for larger market capitalization of Indian listed companies.

For further estimation and analysis, the percentage monthly returns are calculated from monthly share prices. The study also includes the characteristics data of stocks such as market capitalization ${ }^{2}(\mathrm{MC})$, price-tobook ratio $^{3}(\mathrm{P} / \mathrm{B})$. Besides above, macroeconomic variables' data such as dividend yield of BSE- $200^{4}$ index, term spread (difference between long-term bond yield and short-term bond yield), and 91-day T-bill ${ }^{5}$ yield are used in the study. The data used in the study are collected from BLOOMBERG database.

\section{Methods}

We start with formation of single-sorted portfolios of the individual securities on the basis of past excess returns and company characteristics such as size and value being measured by $\mathrm{MC}$ and $\mathrm{P} / \mathrm{B}$ ratio, respectively. Then we form double-sorted portfolios to arrive at the mimicking

\footnotetext{
1 The original source of database (BLOOMBERG) provides monthly closing price and adjusted closing price. Generally, the companies may go for periodical capital changes such as stocks split, right issues, and stock dividend. However, general closing price of the stocks does not adjust for these capital changes. While adjusted closing prices of the sample stocks do adjust for the capital changes if they occur. Hence, stock returns calculated from adjusted closing prices will reflect the true performance of the stocks. Further, the returns calculated from the adjusted share prices will produce unbiased results.

2 The study takes MC as a measure of firm size by following the global convention. Further, the study does not use $\mathrm{MC}$ as the original form of dataset rather the natural logarithmic value of MC for sample stocks is used. Moreover, $\mathrm{MC}$ is taken for the month of June every year with the assumption that the information of $\mathrm{MC}$ will reach the investors after three months from closing month (March) of the accounting year.

${ }^{3}$ Following the practice of research in asset pricing in India, the study employs $\mathrm{P} / \mathrm{B}$ ratio as a measure of firm value. This is the subjectivity of the researchers to use either $\mathrm{P} / \mathrm{B}$ ratio or book equity-to-market equity (BE/ $\mathrm{ME})$ ratio as the measure of firm value. As $\mathrm{BE} / \mathrm{ME}$ is not directly available in the original data source, the study uses $\mathrm{P} / \mathrm{B}$ ratio which is inverse to $\mathrm{BE} /$ ME. FF (1993) uses BE/ME as a measure of firm value and the same as used to form mimicking portfolio of HML. Hence, our interpretation on $\mathrm{P} / \mathrm{B}$ is opposite to that of FF (1993).

4 The study uses BSE-200 monthly return being calculated from monthly adjusted closing prices of the index. Further above return is adjusted for risk free return to obtain excess market return which is the proxy for market portfolio. This entails as market return which is one of the independent variables to run the OLS.

5 There are different government securities available in Indian government securities market from which risk-free rate of interest could be calculated. However, by convention, the study uses returns on 91-day T-bill which is one of the risk-free short-term financial assets in Indian money market.
} 
portfolios such as SMB, LMH, and WML (definitions for these abbreviations are presented in the later section). The next set of double sorting is carried out considering momentum returns and macroeconomic variables to examine the impact of macroeconomic variables on momentum returns.

\section{Single-sorted portfolios}

Single-sorted portfolios are constructed using JT-1993 methodology. The portfolios are based on $j / k$ months strategy where $j$ months represent portfolio formation period while $k$ months denote portfolio holding period. The stocks are ranked according to their past returns based on respective investment strategies (3-3, 6-6, $12-12,36-36$, and $60-60$ months). We start with $3-3$ investment strategy. In the month of October 2002, the stocks are ranked on the basis of their past three-month average excess returns and classified into five portfolios, $P_{1}$ to $P_{5}$ where $P_{1}$ consists of bottom 20 percent of the sample stocks and $P_{5}$ contains of top 20 percent of the stocks. Then equally weighted excess returns are estimated for next three months for respective portfolios.This process is replicated for portfolio formation for other time windows as well till November 2018.

\section{Double-sorted portfolios}

Size, value, and past excess returns are used to form double-sorted portfolios. $\mathrm{MC}$ and $\mathrm{P} / \mathrm{B}$ ratio are used to form size-value portfolios, whereas $\mathrm{MC}$ and the cumulative returns (CRs) are used to form size-momentum portfolios. In the month of June of year $t$, the sample securities are ranked and sorted into two groups, namely small and big by taking MC. The above size classification of small is symbolized by ' $S$ ' and big is abbreviated as ' $B$ '. Then the same sample stocks are again ranked on $\mathrm{P} / \mathrm{B}$ ratio and made three groups such as low, medium, and high. The value classification of low is symbolized by $L$, medium is abbreviated as $M$, and High is shortened to be $H$. We follow the breakpoint convention of using 50:50 for ranking the stocks on size and 33.33, 33.33, and 33.33 for ranking the securities on $\mathrm{PB}$ ratio. We intersect two size groups and three value groups and get six portfolios of $S / L, S / M$, $\mathrm{S} / \mathrm{H}, \mathrm{B} / \mathrm{L}, \mathrm{B} / \mathrm{M}$, and $\mathrm{B} / \mathrm{H}$ where $\mathrm{S} / \mathrm{L}$ includes small size and low value stocks, whereas $\mathrm{B} / \mathrm{H}$ carries big size and high value stocks. Next, equally weighted excess returns are calculated on each of the above six portfolios from July $2002(t)$ to June $2003(t+1)$. Then, as part of review of portfolios' performance, portfolios are rebalanced in June 2003. Further, in the process of rebalancing portfolios, stocks may get displaced from their original characteristics such as small and big and so on. The stocks that could be small in terms of size in one year may become big in another year in the process of rebalancing. Then we form size-momentum portfolios using the same breakpoints as that of size-value portfolios. Next, keeping size classification constant, we rank the sample securities on 11-month cumulative returns and make three groups, namely loser (symbolized by L), neutral $(\mathrm{N})$, and winner $(\mathrm{W})$. Then by getting size intersected with momentum, six portfolios, namely $\mathrm{S} / \mathrm{L}, \mathrm{S} / \mathrm{N}, \mathrm{S} / \mathrm{W}, \mathrm{B} / \mathrm{L}, \mathrm{B} / \mathrm{N}$, and $\mathrm{B} / \mathrm{W}$, are formed. $\mathrm{S} / \mathrm{L}$ is a combination of portfolio which includes small size and loser stocks, whereas $\mathrm{B} / \mathrm{W}$ carries a portfolio which contains big size and winner stocks. Next, equally weighted excess returns are calculated on each of the above six portfolios from July 2002 $(t)$ to June $2003(t+1)$. Then we rebalance the portfolios in June 2003, and this rebalancing of portfolios is carried out until the study period gets over. Further, in the process of rebalancing, change of stocks' characteristics from loser to winner and vice versa is quite possible. Hence in order to have accosted approach as portfolio strategy to make significant returns on portfolios, the portfolios are rebalanced every year. However excess returns on above six portfolios are not reported in the study as the purpose of the estimation of these returns is to form mimicking portfolios such as SMB, LMH, and WML.

Next, we adopt the methodology of Fama-French (1993) and Sehgal-Jain (2014) to form mimicking portfolios such as SMB, LMH, and WML. SMB is an abbreviation of "small minus big" which mimics for the portfolio's risk in relation to company size. LMH has the expansion of "low minus high" which mimics for the risk involved in portfolio's return with regard to company value. Finally, WML is the short form for "winner minus loser" which mimics the risk involved in stocks' prior returns (Momentum factor) during different time horizon. The formulas for the above mimicking portfolios are as follows.

SMB (small minus big)

$$
\mathrm{SMB}=(S / L+S / M+S / H) / 3-(B / L+B / M+B / H) / 3
$$

LMH (low minus high)

$$
\mathrm{LMH}=(S / L+B / L) / 2-(S / H+B / H) / 2
$$

WML (winner minus loser)

$$
\mathrm{WML}=(S / W+B / W) / 2-(S / L+B / L) / 2
$$

\section{Sorting of forecasted portfolios on the basis of macroeconomic variables}

The study uses three important macroeconomic variables related to stock market to predict the return and then examines the importance of these predicted returns in explaining momentum returns as done in the previous studies by forming portfolios based on these returns. 
The variables are dividend yield, term spread, and 91-day T-bill yield. The empirical underpinning behind using these variables is as follows.

In this study, dividend yield refers to the dividend yields of BSE-200 index over past 12 months. Previous studies have shown that this factor is related to slow mean reversion as it has a direct impact on the stock prices. Stock prices tend to change to the dividend payments. Stock prices are less when the discount rate and expected returns are high and vice versa. Hence this factor is used as proxy for time variation in the unobservable risk premiums. The term spread is the difference between month yield on 10-year long-term bond and 91-day T-bill. This variable is included in the study because it is closely related to short-term business cycle. Yield on 91-day T-bill is negatively related to future market returns because current yield on T-bill contains the future expected yield. Hence, increase or decrease in interest rate has a definite impact on stock returns. Thus, this variable is expected to proxy for future economic activity.

Next, to test the above, we regress the returns on each stock for last 60 months for three macroeconomic variables using the following regression equation:

$$
R_{\mathrm{it}}=\alpha_{\mathrm{it}}+\beta_{i 1} \mathrm{DIV}_{t}+\beta_{i 2} \mathrm{TERM}_{t}+\beta_{i 3} \mathrm{YLD}_{t}+e_{\mathrm{it}}
$$

where $R_{\mathrm{it}}, \alpha_{\mathrm{it}}, \beta_{i 1}, \beta_{i 2}$, and $\beta_{i 3}$ denote the returns of stock, intercept, and the sensitivity coefficient of stock $i$ in month $t$, respectively, whereas $\mathrm{DIV}_{t}, \mathrm{TERM}_{t}, \mathrm{YLD}_{t}$ are termed as dividend yield of the BSE-200 index, term spread (difference between yield of long-term bond and 91-day Treasury bill), and 91-day T-bill yield.

The value of the factor loadings (intercept and the sensitivity coefficients) is obtained from the above regression to predict future returns based on macroeconomic variables. The returns are predicted for next six months using above factor loadings, and then equally weighted portfolios are formed based on these forecasted returns. After that, the initial six months are excluded from 60 months and the six months for which returns are already predicted are added to the data to predict the return for the next six months and the process is repeated till the end of the time period considered for the study.

Twenty-five portfolios $(5 * 5)$ are formed by using predicted returns derived from factor loadings of macroeconomic variables and actual average returns of the stocks. To form those 25 portfolios, the stocks are divided into quintile $\left(\mathrm{FP}_{1}\right.$ to $\left.\mathrm{FP}_{5}\right)$ based on predicted returns and then within each quintile the stocks are again ranked into quintiles $\left(\mathrm{FP}_{1}\right.$ to $\left.\mathrm{FP}_{5}\right)$ by using their actual average returns. If any of the portfolios formed on average returns and conditioned on predicted return generate positive returns, then it can be concluded that the model based on macroeconomic variables is unable to explain the available momentum returns in Indian stock market.

\section{Results and discussion}

\section{Evidence of momentum returns on portfolios}

Table 1 shows the average return, standard deviation, and $t$-value of portfolios sorted on returns of sample stocks. After forming portfolios for different trading strategies that are explained above, first we calculate mean excess return on each portfolio to check the availability of momentum returns in Indian stock market. Next, standard deviation is calculated to measure the monthly variances of the returns on sample stocks. Then t-statistics for different portfolios are computed to verify whether returns generated by portfolios are statistically significant. If the mean returns on portfolios of any trading strategies are positive, then it shows the availability of positive momentum returns in Indian stock market.

Table 1 shows availability of strong momentum returns in Indian stock market as almost all the portfolios based on past returns of the trading strategies generate positive average returns. Specifically, the portfolios which contain the top twenty percent stocks provide highest returns which are $0.022,0.026,0.024,0.022$, and 0.314 in the case 3-3, 6-6, 12-12, 36-36, 60-60 strategies, respectively. The t-statistics of all the above portfolios are statistically significant at $5 \%$ level (two- tail). Further, it is clearly observed that the portfolios' average returns exhibit a pattern of being lower to higher average returns on loser portfolio to winner portfolio. This average return pattern exactly meets the core premise of the momentum strategy.

\section{Momentum returns and risk models}

It is a well-documented fact that strong momentum returns are available in Indian stock market. As discussed above, debate over the sources of momentum returns is also evident as lot of studies has been carried out across the world to find an appropriate answer to it. Despite a plethora of work on this debate, there is no conclusive evidence about the sources of momentum returns. Of late, some researchers suggested some risk models that consist of risk factors related to stocks can explain the momentum returns. Risk models such as CAPM, FF-3 factor model, and Carhart four-factor model gain importance over the time as these models are tested widely by researchers across the globe and found to be explaining the momentum returns up to certain extent. In the case of Indian stock market, it is not different as well. Some studies test these models and find that they can partially explain the underlying momentum returns. This study revisits the above fact and tests the power of these 
Table 1 Descriptive statistics for the portfolios sorted on past returns for different trading strategies

\begin{tabular}{llllll}
\hline Portfolios & $\mathbf{1}$ & $\mathbf{2}$ & $\mathbf{3}$ & $\mathbf{4}$ & $\mathbf{5}$ \\
\hline $3^{*} 3$ & & & & & \\
Mean & 0.012 & 0.012 & 0.015 & 0.016 & 0.022 \\
Standard deviation & 0.103 & 0.087 & 0.084 & 0.085 & 0.081 \\
T-statistics & 1.635 & 1.918 & 2.534 & 2.684 & 3.757 \\
$6^{*} 6$ & & & & & \\
Mean & 0.016 & 0.016 & 0.015 & 0.019 & 0.026 \\
Standard deviation & 0.101 & 0.084 & 0.073 & 0.071 & 0.077 \\
T-statistics & 2.202 & 2.706 & 2.823 & 3.781 & 4.837 \\
12*12 & & & & & \\
Mean & 0.009 & 0.008 & 0.011 & 0.014 & 0.024 \\
Standard deviation & 0.086 & 0.066 & 0.059 & 0.056 & 0.06 \\
T-statistics & 1.580 & 1.675 & 2.611 & 3.434 & 5.558 \\
36*36 & & & & & \\
Mean & 0.007 & 0.008 & 0.010 & 0.014 & 0.022 \\
Standard deviation & 0.092 & 0.068 & 0.060 & 0.057 & 0.059 \\
T-statistics & 1.029 & 1.495 & 2.225 & 3.127 & 4.741 \\
60*60 & & & & & \\
Mean & 0.014 & 0.020 & 0.019 & 0.023 & 0.031 \\
Standard deviation & 0.087 & 0.068 & 0.057 & 0.054 & 0.056 \\
T-statistics & 2.217 & 4.094 & 4.640 & 5.929 & 7.683 \\
\hline Thersutsar & & & & \\
\hline
\end{tabular}

The results are presented from authors' own data computation

This table records mean returns, standard deviation, and $t$-statistics for different portfolios. $T$-statistics as a measure of statistical significance shows that 21 out of 25 portfolios mentioned below yield statistically significant returns ( $5 \%$ level). This is substantiated from the values of $t$-statistics being shown in the present table

prominent risk models in explaining the momentum returns with an updated dataset in terms of time period and the sample used for the study which is shown in this section.

\section{Capital asset pricing model (CAPM)}

Capital asset pricing model (CAPM) of Sharpe (1964), Linter (1965), and Black (1965) solves the quest of risk and expected return relationship over a long period of time for academicians, researchers, and empiricists. Hence, in this study, we employ CAPM to check whether the risk factor is accounted for above unexplained returns. For that, we regress the excess return on each portfolio for the excess return on market. An excess return version of market model is used to run CAPM which is stated below.

$$
R_{\mathrm{pt}}-R_{\mathrm{ft}}=\alpha+\beta\left(R_{\mathrm{mt}}-R_{\mathrm{ft}}\right)+e_{t}
$$

where $R_{\mathrm{pt}}-R_{\mathrm{ft}}$ refers to the excess return of portfolio over the risk-free rate. The $\alpha$ denotes the abnormal return on portfolio which is otherwise called as intercept term. $\beta$ is called the sensitivity coefficient of excess market return, and $R_{\mathrm{mt}}-R_{\mathrm{ft}}$ is the excess market return over the risk-free rate. Finally, $e_{t}$ is the disturbance term which includes the factors that are not considered in the model.

Table 2 shows the results of CAPM for both the shortterm and long-term periods starting from 3-3-month strategy to 60-60-month strategy. The failure of CAPM to capture the momentum returns is clearly indicative as the resulting alphas are positive and nonzeros. The alphas of both loser and winner portfolio are 0.015, 0.025, 0.013, $0.029,0.014,0.028,0.003,0.023,0.010,0.029$ in the case of 3-3, 6-6, 12-12, 36-36, 60-60 investment strategies, respectively. Almost all the $t(\alpha)$ values of the portfolios are significant at $5 \%$ level of significance. The $R^{2}$ values of all the portfolios are around 70\% (goodness of fit) across the time periods which is the explanatory powers of the variables used in the model about the extra-normal returns in the portfolios. To sum up from the above interpretation, CAPM is unable to explain the abnormal returns of portfolios in Indian stock market.

\section{Fama-French (FF) three-factor model}

The inability of CAPM to explain the excess reruns paves way for the genesis of a new dynamic model, namely three-factor model, which is originally developed by Fama-French (1993) which takes into consideration of firm size and value factors along with market factor documented by CAPM. As is the case, we also go on to test FF three-factor model due to the failure of CAPM and to solve the quest of whether this model can explain the momentum returns in Indian stock market. The model specification of FF three-factor model is: -

$$
R_{\mathrm{Pt}}-R_{\mathrm{Ft}}=\alpha+\beta\left(R_{\mathrm{Mt}}-R_{\mathrm{Ft}}\right)+s \mathrm{SMB}_{t}+l \mathrm{LMH}_{t}+e_{t}
$$

where SMB is the mimicking portfolio for size factor and $\mathrm{LMH}$ is the mimicking portfolio for value factor; $s$ and $l$ are the sensitivity coefficients.

The following tables show the results of FF three-factor model of both short-term $(3-3,6-6,12-12)$ and longterm $(36-36,60-60)$ investment strategies. According to pricing theory, the intercept value of the time series regression shall be equal to zero so as to ensure that the model is efficient to explain momentum returns. If we look at the alphas, the alphas of the winner portfolios of $3-3,6-6,12-12,36-36$, and 60-60 strategies are attenuated and the alphas are in the ranges of $0.16,0.018,0.018$, 0.008 , and 0.008 , respectively. In the case of loser portfolios, the alphas are close to zero but still significant. The $t(\alpha)$ of almost all portfolios across the time periods is significant at $5 \%$ level. Though $R^{2}$ values improve compared to the CAPM, still it is inconclusive to draw a clear verdict on the fact that FF-3 factor model has the power 
Table 2 Results of CAPM over different trading strategies

\begin{tabular}{|c|c|c|c|c|c|}
\hline Portfolios & $a$ & $\beta$ & $t(a)$ & $t(\beta)$ & $R^{2}$ \\
\hline \multicolumn{6}{|l|}{$3 / 3$} \\
\hline$P_{1}$ & 0.015 & 1.183 & 3.653 & 21.59 & 0.735 \\
\hline$P_{2}$ & 0.015 & 1.085 & 4.97 & 26.858 & 0.811 \\
\hline$P_{3}$ & 0.016 & 1.045 & 5.728 & 28.154 & 0.825 \\
\hline$P_{4}$ & 0.018 & 1.038 & 5.863 & 25.561 & 0.795 \\
\hline$P_{5}$ & 0.025 & 1.065 & 7.032 & 22.227 & 0.746 \\
\hline \multicolumn{6}{|l|}{$6 / 6$} \\
\hline$P_{1}$ & 0.013 & 1.206 & 3.086 & 21.465 & 0.736 \\
\hline$P_{2}$ & 0.015 & 1.074 & 4.749 & 24.773 & 0.788 \\
\hline$P_{3}$ & 0.013 & 1.029 & 4.983 & 28.904 & 0.835 \\
\hline$P_{4}$ & 0.02 & 1.023 & 7 & 27.282 & 0.798 \\
\hline$P_{5}$ & 0.029 & 1.09 & 7.956 & 22.559 & 0.755 \\
\hline \multicolumn{6}{|l|}{$12 / 12$} \\
\hline$P_{1}$ & 0.014 & 1.225 & 2.824 & 18.511 & 0.683 \\
\hline$P_{2}$ & 0.011 & 1.064 & 3.481 & 24.338 & 0.788 \\
\hline$P_{3}$ & 0.014 & 1.052 & 4.727 & 26.32 & 0.813 \\
\hline$P_{4}$ & 0.019 & 0.985 & 6.636 & 26.185 & 0.812 \\
\hline$P_{5}$ & 0.028 & 1.046 & 8.431 & 23.427 & 0.775 \\
\hline \multicolumn{6}{|l|}{$36 / 36$} \\
\hline$P_{1}$ & 0.007 & 1.72 & 1.185 & 12.819 & 0.731 \\
\hline$P_{2}$ & 0.008 & 1.313 & 1.901 & 14.278 & 0.772 \\
\hline$P_{3}$ & 0.011 & 1.213 & 3.734 & 19.692 & 0.866 \\
\hline$P_{4}$ & 0.014 & 1.118 & 4.333 & 15.486 & 0.799 \\
\hline$P_{5}$ & 0.023 & 1.09 & 5.575 & 12.369 & 0.717 \\
\hline \multicolumn{6}{|l|}{$60 / 60$} \\
\hline$P_{1}$ & 0.01 & 1.693 & 1.169 & 7.654 & 0.615 \\
\hline$P_{2}$ & 0.017 & 1.446 & 3.036 & 10.387 & 0.748 \\
\hline$P_{3}$ & 0.017 & 1.286 & 4.291 & 13.484 & 0.834 \\
\hline$P_{4}$ & 0.021 & 1.146 & 4.567 & 10.163 & 0.74 \\
\hline$P_{5}$ & 0.029 & 1.121 & 5.241 & 8.177 & 0.647 \\
\hline
\end{tabular}

The results are presented from authors' own data computation

to explain the abnormal returns of portfolios sorted on momentum returns (Table 3 ).

\section{Carhart four-factor model (CFF)}

The failure of FF three-factor model motivates us to test the CFF model which adds momentum as an additional factor along with other factors in the FF three-factor model. The objective remains same that is whether this four-factor model can explain momentum returns better than FF three-factor model. The CFF model's model specification is: -

$$
\begin{aligned}
R_{\mathrm{Pt}}-R_{\mathrm{Ft}}= & \alpha+\beta\left(R_{\mathrm{Mt}}-R_{\mathrm{Ft}}\right)+s \mathrm{SMB}_{t} \\
& +l \mathrm{LMH}_{t}+w \mathrm{WML}_{t}+e_{t}
\end{aligned}
$$

where WML is a mimicking portfolio which reflects the firms' risk involved in momentum return and it is calculated by subtracting returns on loser portfolio from returns on winner portfolio. $w$ is the sensitivity coefficient of momentum factor.

Table 4 presents the regression results of CFF model by using the portfolios return and the underlying risk factors such as market risk, size, value, and momentum for both the short-term and long-term time periods. If we look in details, in the case of long-term investment strategies, the alphas of loser and winner portfolios are close to zero which are $0.005,0.005$, and $0.002,0.006$ for $36-36$ and 60-60 investment strategies, respectively, whereas the results show a contradictory result in the case of shortterm momentum strategies as the resulting alphas of both the loser and winner portfolios are positive and nonzeros such as $0.010,0.011,0.010,0.013$, and $0.013,0.014$ for $3-3,6-6,12-12$ investment strategies, respectively. In this case, also the $t(\alpha)$ values are significant at $5 \%$ level for almost all the portfolios across the time periods. The results also show the improved $R^{2}$ value compared to previous two models in all the cases which also indicate that the model has better explanatory power. Though it gives better results $v i s-\grave{a}-v i s$ other models, still we find positive intercept in the case of certain portfolios for some of the investment strategies. Hence, one can conclude that the model partially explains momentum returns which is in line with previous notable studies.

\section{Macroeconomic variables}

As discussed above, researchers have found some empirical evidences about the importance of macroeconomic variables in explaining the abnormal returns on portfolios consisting of various diversified assets in it. Predominantly in developed stock markets, it is found that momentum returns disappear once cross-sectional differences in predicted returns are controlled by using lagged macroeconomic variables. This study attempts to test the same by considering momentum in Indian stock market which is one of the fastest growing stock markets across the world and attracted very a smaller number of studies those have considered this gap.

We see in the previous section that well-established risk models fail to explain momentum returns. As a result, in this section we try to examine the role of macroeconomic variables in explaining momentum returns which are important measures of market conditions. To study the macroeconomic effect, we first forecast the return based on three important macroeconomic variables (dividend yield, term spread, and 91-day Treasury bill yield). Then portfolios are sorted considering this forecasted return and the normal return of sample stocks as well. Then the average returns are obtained from portfolio formed by intersecting both forecasted return and normal return. If 
Table 3 Results of FF-3 factor model for different trading strategies

\begin{tabular}{|c|c|c|c|c|c|c|c|c|c|}
\hline Portfolios & $a$ & $\beta$ & $s$ & $I$ & $t(a)$ & $t(\beta)$ & $t(s)$ & $t(I)$ & $R^{2}$ \\
\hline \multicolumn{10}{|l|}{$3 * 3$} \\
\hline$P 1$ & 0.005 & 1.067 & 0.639 & 0.523 & 1.546 & 23.154 & 6.635 & 6.289 & 0.844 \\
\hline$P 2$ & 0.006 & 1.029 & 0.601 & 0.245 & 2.617 & 30.326 & 8.483 & 4.008 & 0.889 \\
\hline P3 & 0.008 & 1.016 & 0.559 & 0.126 & 3.428 & 30.854 & 8.131 & 2.128 & 0.885 \\
\hline P4 & 0.01 & 1.012 & 0.606 & 0.113 & 3.586 & 27.662 & 7.925 & 1.707 & 0.862 \\
\hline P5 & 0.016 & 1.041 & 0.689 & 0.104 & 4.919 & 23.552 & 7.467 & 1.304 & 0.82 \\
\hline \multicolumn{10}{|l|}{$6^{*} 6$} \\
\hline$P 1$ & 0.003 & 1.114 & 0.651 & 0.401 & 0.838 & 21.967 & 6.123 & 4.384 & 0.821 \\
\hline$P 2$ & 0.007 & 0.999 & 0.574 & 0.326 & 2.497 & 27.069 & 7.42 & 4.893 & 0.872 \\
\hline P3 & 0.005 & 0.987 & 0.545 & 0.177 & 2.452 & 32.593 & 8.574 & 3.245 & 0.901 \\
\hline P4 & 0.011 & 0.98 & 0.572 & 0.183 & 4.85 & 30.579 & 8.506 & 3.169 & 0.89 \\
\hline P5 & 0.018 & 1.076 & 0.754 & 0.043 & 5.74 & 24.62 & 8.219 & 0.551 & 0.833 \\
\hline \multicolumn{10}{|l|}{$12 * 12$} \\
\hline$P 1$ & 0.004 & 1.128 & 0.671 & 0.46 & 0.913 & 18.325 & 5.259 & 4.067 & 0.771 \\
\hline$P 2$ & 0.004 & 1.009 & 0.533 & 0.264 & 1.286 & 25.6 & 6.53 & 3.657 & 0.857 \\
\hline P3 & 0.007 & 1.014 & 0.499 & 0.181 & 2.601 & 27.523 & 6.54 & 2.676 & 0.868 \\
\hline P4 & 0.01 & 0.93 & 0.609 & 0.263 & 4.79 & 32.897 & 10.396 & 5.075 & 0.911 \\
\hline P5 & 0.018 & 1.081 & 0.798 & -0.153 & 6.279 & 28.427 & 10.119 & -2.187 & 0.864 \\
\hline \multicolumn{10}{|l|}{$36 * 36$} \\
\hline$P 1$ & 0.001 & 0.980 & 0.526 & 1.015 & 0.254 & 11.890 & 4.645 & 13.313 & 0.939 \\
\hline$P 2$ & 0.000 & 0.861 & 0.586 & 0.574 & 0.028 & 13.143 & 6.515 & 9.473 & 0.931 \\
\hline P3 & 0.004 & 0.984 & 0.487 & 0.258 & 1.666 & 18.444 & 6.650 & 5.237 & 0.940 \\
\hline P4 & 0.003 & 0.997 & 0.750 & 0.050 & 1.298 & 16.458 & 9.019 & 0.895 & 0.915 \\
\hline P5 & 0.008 & 1.138 & 0.968 & -0.243 & 3.101 & 18.700 & 11.582 & -4.307 & 0.919 \\
\hline \multicolumn{10}{|l|}{$60 * 60$} \\
\hline$P 1$ & -0.001 & 0.878 & 0.506 & 1.073 & -0.352 & 8.723 & 4.182 & 13.755 & 0.945 \\
\hline$P 2$ & 0.006 & 0.955 & 0.472 & 0.588 & 1.857 & 11.546 & 4.738 & 9.164 & 0.939 \\
\hline P3 & 0.005 & 1.056 & 0.523 & 0.169 & 1.562 & 13.037 & 5.368 & 2.699 & 0.918 \\
\hline P4 & 0.004 & 0.974 & 0.775 & -0.008 & 1.267 & 11.567 & 7.646 & -0.130 & 0.900 \\
\hline P5 & 0.008 & 1.053 & 1.032 & -0.257 & 2.724 & 15.860 & 12.915 & -4.989 & 0.943 \\
\hline
\end{tabular}

The results are presented from authors' own data computation

any of the portfolios formed based on momentum return and conditioned by forecasted return using macroeconomic variables found to be profitable, that gives us the conclusion that macroeconomic has no power to explain the abnormal returns of portfolios and vice versa.

Table 5 reports the average returns that are obtained by intersecting the forecasted return based on macroeconomic variables and momentum returns of various investment strategies over different time horizon along with their t-statistics in square brackets. The furnished results in the table below are hallucinatory in nature as one might think macroeconomic variables explain the momentum returns. If we look at the results in detail, almost all the portfolios across time the periods generate significant positive returns which entail us to conclude that macroeconomic variables have no power to explain the underlying momentum returns in Indian stock market.

Specifically, the returns of winner portfolios are higher among all other portfolios. The average of all higher predicted quintile and lower predicted quintile portfolios is $1.30,2.18,1.64,2.44,1.20,1.78,1.34,1.72$, and $2.38,2.64$ percent for $3-3,6-6,12-12,36-36$, and 60-60 investment strategies, respectively. The $t$ statistics of all the portfolios are also significant at 5 percent level of significance. Furthermore, the difference in mean returns between higher return portfolios and lower return portfolios $\left(P_{5}-P_{1}\right)$ is also significant in all portfolios with significant $\mathrm{t}$ statistics across the time periods. Hence, these results lend strong support to the fact that macroeconomic variables are unable to explain the momentum return of various trading strategies in Indian stock market. 
Table 4 Results of CFF model over different trading strategies

\begin{tabular}{|c|c|c|c|c|c|c|c|c|c|c|c|}
\hline Portfolios & $A$ & $\beta$ & $s$ & $L$ & $w$ & $t(a)$ & $t(\beta)$ & $t(s)$ & $t(l)$ & $t(w)$ & $R^{2}$ \\
\hline \multicolumn{12}{|l|}{$3 * 3$} \\
\hline$P_{1}$ & 0.01 & 1.036 & 0.59 & 0.353 & -0.635 & 4.174 & 30.44 & 8.307 & 5.622 & -11.881 & 0.916 \\
\hline$P_{2}$ & 0.008 & 1.018 & 0.583 & 0.182 & -0.237 & 3.568 & 31.739 & 8.718 & 3.078 & -4.699 & 0.902 \\
\hline$P_{3}$ & 0.008 & 1.018 & 0.563 & 0.138 & 0.045 & 3.217 & 30.808 & 8.162 & 2.269 & 0.871 & 0.886 \\
\hline$P_{4}$ & 0.007 & 1.026 & 0.627 & 0.188 & 0.283 & 2.866 & 30.149 & 8.839 & 2.994 & 5.296 & 0.882 \\
\hline$P_{5}$ & 0.011 & 1.072 & 0.738 & 0.271 & 0.625 & 4.514 & 33.596 & 11.085 & 4.595 & 12.477 & 0.907 \\
\hline \multicolumn{12}{|l|}{$6 * 6$} \\
\hline$P_{1}$ & 0.01 & 1.086 & 0.596 & 0.184 & -0.718 & 3.588 & 28.531 & 7.472 & 2.583 & -11.342 & 0.9 \\
\hline$P_{2}$ & 0.011 & 0.983 & 0.543 & 0.204 & -0.401 & 4.49 & 30.831 & 8.13 & 3.427 & -7.563 & 0.906 \\
\hline$P_{3}$ & 0.006 & 0.984 & 0.539 & 0.156 & -0.072 & 2.714 & 32.534 & 8.498 & 2.75 & -1.43 & 0.902 \\
\hline$P_{4}$ & 0.01 & 0.986 & 0.584 & 0.23 & 0.155 & 4.189 & 31.434 & 8.872 & 3.926 & 2.974 & 0.896 \\
\hline$P_{5}$ & 0.013 & 1.097 & 0.794 & 0.205 & 0.533 & 4.852 & 30.473 & 10.522 & 3.044 & 8.907 & 0.888 \\
\hline \multicolumn{12}{|l|}{$12 * 12$} \\
\hline$P_{1}$ & 0.013 & 1.086 & 0.662 & 0.033 & -0.93 & 5.577 & 34.338 & 10.118 & 0.531 & -21.024 & 0.94 \\
\hline$P_{2}$ & 0.009 & 0.986 & 0.528 & 0.032 & -0.507 & 4.283 & 36.474 & 9.451 & 0.61 & -13.391 & 0.933 \\
\hline$P_{3}$ & 0.01 & 1 & 0.496 & 0.033 & -0.322 & 4.241 & 31.097 & 7.464 & 0.531 & -7.159 & 0.9 \\
\hline$P_{4}$ & 0.009 & 0.933 & 0.61 & 0.289 & 0.055 & 4.472 & 33.012 & 10.435 & 5.26 & 1.381 & 0.912 \\
\hline$P_{5}$ & 0.014 & 1.098 & 0.801 & 0.009 & 0.353 & 5.834 & 33.786 & 11.927 & 0.146 & 7.757 & 0.902 \\
\hline \multicolumn{12}{|l|}{$36 * 36$} \\
\hline$P_{1}$ & 0.005 & 1.094 & 0.735 & 0.224 & -0.792 & 2.027 & 16.540 & 7.864 & 1.620 & -6.296 & 0.963 \\
\hline$P_{2}$ & 0.003 & 0.936 & 0.723 & 0.058 & -0.517 & 1.297 & 16.040 & 8.770 & 0.475 & -4.663 & 0.949 \\
\hline$P_{3}$ & 0.004 & 1.001 & 0.519 & 0.134 & -0.123 & 1.928 & 18.114 & 6.654 & 1.164 & -1.177 & 0.940 \\
\hline$P_{4}$ & 0.001 & 0.958 & 0.680 & 0.314 & 0.264 & 0.672 & 15.767 & 7.921 & 2.467 & 2.290 & 0.921 \\
\hline$P_{5}$ & 0.005 & 1.089 & 0.879 & 0.092 & 0.336 & 2.374 & 18.356 & 10.486 & 0.746 & 2.979 & 0.928 \\
\hline \multicolumn{12}{|l|}{$60 * 60$} \\
\hline$P_{1}$ & 0.002 & 0.963 & 0.839 & 0.151 & -0.827 & 0.783 & 12.266 & 7.374 & 0.781 & -4.99 & 0.968 \\
\hline$P_{2}$ & 0.008 & 0.993 & 0.620 & 0.175 & -0.369 & 2.437 & 12.367 & 5.328 & 0.886 & -2.180 & 0.945 \\
\hline$P_{3}$ & 0.004 & 1.036 & 0.448 & 0.374 & 0.184 & 1.256 & 12.515 & 3.735 & 1.831 & 1.054 & 0.918 \\
\hline$P_{4}$ & 0.003 & 0.959 & 0.718 & 0.145 & 0.138 & 1.033 & 11.050 & 5.708 & 0.679 & 0.755 & 0.899 \\
\hline$P_{5}$ & 0.006 & 1.019 & 0.901 & 0.103 & 0.323 & 2.230 & 16.042 & 9.780 & 0.660 & 2.411 & 0.950 \\
\hline
\end{tabular}

The results are presented from authors' own data computation

\section{Practical implications of the study}

- The results of the study reveal that momentum pattern in Indian stock market persists. The study experiments the presence of momentum in different strategies covering different time horizon. However, strong momentum pattern is observed in 6-6 trading strategy as it fetches the highest returns. Hence, the investors of different classes may consider 6-6 momentum-based trading strategy to earn higher rate of returns on their equity investment. However, investment horizon $60 \times 60$ could be the best strategy for the investors who are inclined to stay in the market for longer time.

- Contemporaneous evidences in financial literature show that a greater role being played by macroeconomic variables in different spheres of finan- cial research being carried out in different financial markets. However, a set of macroeconomic variables are considered in this study to verify whether any role is played by them in momentum returns. The results are counterintuitive. Hence, fund managers, portfolio analysts, market practitioners, investors, and other key stake holders of the market may not consider macroeconomic variables as they do not impact the stock returns from momentum strategy perspective.

- Globally eminent academic researchers have evolved several asset pricing models which are capable of explaining excess returns on portfolios based on different strategies. The above models are widely and extensively tested and proved their efficacy in financial markets universally. However, 
Table 5 Results of power of macroeconomic variables in explaining momentum returns over different trading strategies

\begin{tabular}{|c|c|c|c|c|c|c|c|}
\hline Portfolios & $P_{1}$ & $P_{2}$ & $P_{3}$ & $P_{4}$ & $P_{5}$ & All mean returns & $P_{5}-P_{1}$ \\
\hline \multicolumn{8}{|l|}{$3 * 3$} \\
\hline $\mathrm{FP}_{1}$ & $0.009(1.123)$ & $0.005(0.83)$ & $0.013(1.925)$ & $0.013(2.173)$ & $0.025(4.233)$ & $0.013(2.0568)$ & $0.017(3.109)$ \\
\hline $\mathrm{FP}_{2}$ & $0.003(0.378)$ & $0.008(1.395)$ & $0.011(1.839)$ & $0.014(2.236)$ & $0.017(3.032)$ & $0.0106(1.776)$ & $0.014(2.655)$ \\
\hline $\mathrm{FP}_{3}$ & $0.013(1.737)$ & $0.014(2.268)$ & $0.015(2.636)$ & $0.012(2.002)$ & $0.016(2.547)$ & $0.014(2.2376)$ & $0.002(0.810)$ \\
\hline $\mathrm{FP}_{4}$ & $0.021(2.669)$ & $0.017(2.615)$ & $0.02(3.257)$ & $0.021(3.439)$ & $0.016(2.451)$ & $0.019(2.8862)$ & $-0.005(-0.218)$ \\
\hline $\mathrm{FP}_{5}$ & $0.015(1.808)$ & $0.016(2.041)$ & $0.019(2.636)$ & $0.022(3.03)$ & $0.037(5.388)$ & $0.0218(2.9806)$ & $0.021(3.579)$ \\
\hline \multicolumn{8}{|l|}{$6^{*} 6$} \\
\hline $\mathrm{FP}_{1}$ & $0.01(1.424)$ & $0.012(2.04)$ & $0.014(2.55)$ & $0.017(3.246)$ & $0.029(5.113)$ & $0.0164(2.8746)$ & $0.019(3.689)$ \\
\hline $\mathrm{FP}_{2}$ & $0.012(1.64)$ & $0.012(2.007)$ & $0.009(1.886)$ & $0.016(3.274)$ & $0.023(4.154)$ & $0.0144(2.5922)$ & $0.011(2.514)$ \\
\hline $\mathrm{FP}_{3}$ & $0.016(2.21)$ & $0.018(2.953)$ & $0.01(1.813)$ & $0.016(2.962)$ & $0.021(3.952)$ & $0.0162(2.778)$ & $0.004(1.742)$ \\
\hline $\mathrm{FP}_{4}$ & $0.023(3.18)$ & $0.022(3.421)$ & $0.019(3.46)$ & $0.021(3.776)$ & $0.028(4.559)$ & $0.0226(3.6792)$ & $0.005(1.379)$ \\
\hline $\mathrm{FP}_{5}$ & $0.019(2.224)$ & $0.019(2.593)$ & $0.024(3.637)$ & $0.025(4.032)$ & $0.035(5.254)$ & $0.0244(3.548)$ & $0.017(3.030)$ \\
\hline \multicolumn{8}{|l|}{$12 * 12$} \\
\hline $\mathrm{FP}_{1}$ & $0.004(0.686)$ & $0.004(0.722)$ & $0.009(2.054)$ & $0.015(3.279)$ & $0.028(5.24)$ & $0.012(2.3962)$ & $0.023(4.554)$ \\
\hline $\mathrm{FP}_{2}$ & $0.005(0.715)$ & $0.009(1.746)$ & 0.008 (1.682) & $0.013(3.152)$ & $0.019(4.219)$ & $0.0108(2.3028)$ & $0.015(3.505)$ \\
\hline $\mathrm{FP}_{3}$ & $0.009(1.525)$ & $0.004(0.926)$ & $0.011(2.475)$ & $0.012(2.629)$ & $0.019(4.122)$ & $0.011(2.3354)$ & $0.009(2.596)$ \\
\hline $\mathrm{FP}_{4}$ & $0.013(2.152)$ & $0.016(3.078)$ & $0.014(2.994)$ & $0.016(3.881)$ & $0.021(4.653)$ & $0.016(3.3516)$ & $0.008(2.501)$ \\
\hline $\mathrm{FP}_{5}$ & $0.016(2.12)$ & $0.01(1.933)$ & $0.014(2.758)$ & $0.016(3.551)$ & $0.033(6.854)$ & $0.0178(3.4432)$ & $0.017(4.734)$ \\
\hline \multicolumn{8}{|l|}{$36 * 36$} \\
\hline $\mathrm{FP}_{1}$ & $0.003(0.47)$ & $0.004(0.786)$ & $0.012(2.658)$ & 0.017 (3.606) & $0.031(5.709)$ & $0.0134(2.6458)$ & $0.028(5.239)$ \\
\hline $\mathrm{FP}_{2}$ & $0.002(0.313)$ & $0.011(2.198)$ & $0.01(2.042)$ & $0.01(2.14)$ & $0.019(4.285)$ & $0.0104(2.1956)$ & $0.017(3.971)$ \\
\hline $\mathrm{FP}_{3}$ & $0.008(1.2)$ & $-0.001(-0.189)$ & $0.009(2.076)$ & $0.01(2.339)$ & $0.016(3.452)$ & $0.0084(1.7756)$ & $0.008(2.252)$ \\
\hline $\mathrm{FP}_{4}$ & $0.017(2.726)$ & $0.013(2.572)$ & $0.01(2.137)$ & $0.019(4.528)$ & $0.018(4.292)$ & $0.0154(3.251)$ & $0.001(1.566)$ \\
\hline $\mathrm{FP}_{5}$ & $0.008(0.967)$ & $0.014(2.54)$ & $0.014(2.649)$ & $0.02(4.149)$ & $0.03(6.414)$ & $0.0172(3.3438)$ & $0.022(5.447)$ \\
\hline \multicolumn{8}{|l|}{$60 * 60$} \\
\hline $\mathrm{FP}_{1}$ & $0.016(2.346)$ & $0.016(2.982)$ & $0.017(4.342)$ & $0.026(5.381)$ & $0.044(7.647)$ & $0.0238(4.5396)$ & $0.027(5.301)$ \\
\hline $\mathrm{FP}_{2}$ & $0.014(2.26)$ & $0.025(4.858)$ & $0.02(4.567)$ & $0.022(5.312)$ & $0.028(6.46)$ & $0.0218(4.6914)$ & $0.014(4.200)$ \\
\hline $\mathrm{FP}_{3}$ & $0.016(2.559)$ & $0.004(0.961)$ & $0.013(3.39)$ & $0.017(4.31)$ & $0.022(4.826)$ & $0.0144(3.2092)$ & $0.006(2.267)$ \\
\hline $\mathrm{FP}_{4}$ & $0.027(4.738)$ & $0.018(3.359)$ & $0.015(3.524)$ & $0.027(6.571)$ & $0.024(6.07)$ & $0.0222(4.8524)$ & $-0.003(1.332)$ \\
\hline $\mathrm{FP}_{5}$ & $0.014(1.999)$ & $0.028(5.139)$ & $0.025(4.57)$ & $0.029(6.228)$ & $0.036(7.415)$ & $0.0264(5.0702)$ & $0.022(5.416)$ \\
\hline
\end{tabular}

The results are presented from authors' own data computation

CFF model plays a greater role in capturing average returns on portfolios based on momentum strategy vis-à-vis other factor models. Hence, portfolio managers, market analysts, and other investors can consider CFF model as part of momentum strategy owing to the fact that four-factor model is able to capture momentum returns partially. The CFF model could enable the above market participants to estimate risk-adjusted returns on momentum portfolios.

\section{Conclusions}

The long-standing quest to find the proper reason behind the availability of abnormal return on portfolios formed by using past average returns on stocks is still unclear. A numerous number of studies are being carried out by researchers in different stock markets of various geographical locations to check the availability of abnormal momentum returns on portfolios consisting of various stocks and find the proper sources that drive momentum returns. The empirical findings of these studies suggest significant availability of extranormal returns. But the findings regarding the source of these returns are still unclear as no study has given concrete evidence about the fact. Indian stock market is not exceptional to that as it also has strong abnormal momentum returns on the portfolios that include stocks which are traded in this market. A handful of studies have tried to find the sources behind these returns but conclusive evidences are yet to be found in Indian stock market. 
So, the foremost objective of the study is to find the sources of abnormal returns on momentum-based portfolios. For this, the study first revisits to verify the availability of momentum returns in Indian stock market which are already found by some previous studies. The next objective of the study is to examine the role played by illustrious risk models such as CAPM, FF three-factor model, and CFF model in explaining such returns. Then the study tries to evince the power of select macroeconomic variables, e.g., dividend yield, term spread, and 91-day T-bill yield in subsuming the abnormal returns in portfolios. The monthly share prices of 478 companies over a time period from 2002 to 2018 are used for analysis purpose. The study uses the widely accepted ordinary least square (OLS) method as is the standard benchmark method in asset pricing domain and dynamic forecasting method as is the principal methodology to arrive at the desired results.

The empirical findings of the study show that strong abnormal momentum returns are available in Indian stock market which is in line with the previous findings. The study also reports that the eminent risk models such as CAPM and FF 3 models fail to capture the abnormal portfolios' return, whereas CFF model gives partial explanation to these returns. Still the study finds significant unexplained returns in some winner portfolios paves way for further examination.

Next, the study also demonstrates and finds that macroeconomic variables have no power in explaining momentum returns as the portfolio formed by using the predicted return provide significant positive returns. The results of the study can be attributable to the theories such as Markowitz portfolio theory 1952), Shape's capital market theory (1964), and the arbitrage pricing theory which is developed by Stephen Ross in the year 1976. However, the study addresses key issue of relation between momentum returns and macroeconomic factors, and it is constrained by not including several other macroeconomic factors such as inflation, index of industrial production (IIP), and GDP. Perhaps inclusion of above other variables may report a different dynamism in the findings. Further this study is experimented on Indian environment and due to its peculiar characteristics; the findings may not be extrapolated to other markets.

\footnotetext{
Abbreviations

CFF: Carhart four-factor; CAPM: Capital asset pricing model; FF-3: Fama-French three-factor; BSE: Bombay stock exchange; MC: Market capitalization; P/B: Price/book ratio; SMB: Small minus big; LMH: Low minus high; WML: Winners minus losers; CR: Cumulative returns; FP: Forecasted portfolio; OLS: Ordinary least square.
}

Acknowledgements

Not applicable.

\section{Authors' contributions}

This study is completed by the joint effort of the both authors. AB shaped the paper by providing the concept and developing the methods. NB analyzed and interpreted the results of the study. Both the authors have read and approved the manuscript.

\section{Authors' information}

A. Balakrishnan an Associate Professor of finance in the Department of Banking Technology, School of Management, Pondicherry University. He is actively researching in the area of finance and he has published several research papers in leading national and international journal.

Nirakar Barik an Assistant Professor of finance in the Department of Commerce, School of Social Science and Languages, Vellore Institute of Technology, VIT University. His area of research is finance and many of his papers are in the process of publication in reputed journals. This work is a part of his doctoral dissertation which is carried out at Pondicherry university.

\section{Funding}

The authors declare that no funding is used for the study.

\section{Availability of data and materials}

The data which are used in this study for analysis are available in the BLOOMBERG database.

\section{Declarations}

\section{Competing interests}

The authors declare that they have no competing interests.

\section{Author details}

${ }^{1}$ Department of Banking Technology, School of Management, Pondicherry University, Pondicherry 605014, India. ${ }^{2}$ Department of Commerce, School of Social Science and Languages, Vellore Institute of Technology, VIT University, Vellore 632014, India.

Received: 4 May 2020 Accepted: 24 August 2021

Published: 28 December 2021

\section{References}

1. Barberis N, Shleifer A, Vishny R (1998) A model of investor sentiment. J Financ Econ 49(3):307-343

2. Berk JB, Green RC, Naik V (1999) Optimal investment, growth options, and security returns. J Financ 54(5):1553-1607

3. Chen NF, Roll R, Ross SA (1986) Economic forces and the stock market. J Bus 59:383-403

4. Chui AC, Titman S, Wei KJ (2010) Individualism and momentum around the world. J Financ 65(1):361-392

5. Conrad J, Kaul G (1998) An anatomy of trading strategies. Rev Financ Stud 11(3):489-519

6. Cooper I, Mitrache A, Priestley R (2019) A global macroeconomic risk model for value, momentum, and other asset classes. J Financ Quant Anal 2019:1-30

7. Daniel K, Hirschleifer D, Subrahmanyam A (1998) Investor psychology and security market under-and overreactions. J Finance 53(6):1839-1885

8. De Bondt WF, Thaler R (1985) Does the stock market overreact? J Financ 40(3):793-805

9. De Bondt WF, Thaler RH (1987) Further evidence on investor overreaction and stock market seasonality. J Financ 42(3):557-581

10. Fama EF, French KR (1996) The CAPM is wanted, dead or alive. J Financ 51(5):1947-1958

11. Frazzini A (2006) The disposition effect and underreaction to news. J Financ 61 (4):2017-2046

12. Griffin JM, Ji X, Martin JS (2003) Momentum investing and business cycle risk: evidence from pole to pole. J Financ 58(6):2515-2547

13. Grinblatt M, Han B (2005) Prospect theory, mental accounting, and momentum. J Financ Econ 78(2):311-339 
14. Grinblatt M, Moskowitz TJ (2002) What do we really know about the cross-sectional relation between past and expected returns? (No. w8744). National Bureau of Economic Research

15. Hobson B (2012) What really causes price momentum?

16. Hutchinson MC, O'Brien JJ (2015) Trend following and macroeconomic risk. Available at SSRN

17. Jegadeesh N, Titman S (1993) Returns to buying winners and selling losers: implications for stock market efficiency. J Financ 48(1):65-91

18. Johnson TC (2002) Volatility, momentum, and time-varying skewness in foreign exchange returns. J Bus Econ Stat 20(3):390-411

19. Liu J, Chao F, Lin YC, Lin CM (2019) Stock prices prediction using deep learning models. arXiv preprint http://arxiv.org/abs/1909.12227

20. Moskowitz TJ, Grinblatt M (1999) Do industries explain momentum? J Financ 54(4):1249-1290

21. Narayan PK, Phan DHB, Bannigidadmath D (2017) Is the profitability of Indian stocks compensation for risks? Emerg Mark Rev 31:47-64

22. Pirrong C (2005) Momentum in futures markets. In: EFA 2005 Moscow meetings pape

23. Sadka R (2006) Momentum and post-earnings-announcement drift anomalies: the role of liquidity risk. J Financ Econ 80(2):309-349
24. Sagi JS, Seasholes MS (2007) Firm-specific attributes and the cross-section of momentum. J Financ Econ 84(2):389-434

25. Schaller $P$ (2005) An evaluation of momentum strategies in commodity spot markets

26. Sehgal S, Balakrishnan I (2002) Contrarian and momentum strategies in the Indian capital market. Vikalpa 27(1):13-20

27. Sehgal S, Balakrishnan I (2004) Momentum Profits, portfolio characteristics and asset pricing models. Decision (0304-0941), 31(2)

28. Sehgal S, Jain S (2012) Prior return patterns in sector returns: evidence for emerging markets. Asian J Finance Acc 4(1):259-277

29. Shefrin H, Statman M (1985) The disposition to sell winners too early and ride losers too long: theory and evidence. J Financ 40(3):777-790

30. Shen Q, Szakmary AC, Sharma SC (2007) An examination of momentum strategies in commodity futures markets. J Futures Mark Futures Opt Other Deriv Prod 27(3):227-256

\section{Publisher's Note}

Springer Nature remains neutral with regard to jurisdictional claims in published maps and institutional affiliations.

\section{Submit your manuscript to a SpringerOpen ${ }^{\circ}$ journal and benefit from:}

- Convenient online submission

- Rigorous peer review

- Open access: articles freely available online

- High visibility within the field

- Retaining the copyright to your article

Submit your next manuscript at $\boldsymbol{\nabla}$ springeropen.com 